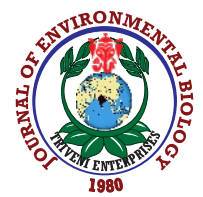

\title{
Destructive dose determination of electron beam irradiation for pathogenic bacteria in water medium by 96 well plate assay
}

\author{
S. Visnuvinayagam ${ }^{1 *}$, L.N. Murthy ${ }^{2}$, U. Parvathy ${ }^{4}$, A. Jeyakumari ${ }^{3}$, K.P. Rawat ${ }^{5}$, S.A. Khadar ${ }^{5}$ and K.S.S. Sarma ${ }^{6}$ \\ ${ }^{1}$ Microbiology Fermentation and Biotechnology Division, ICAR- CIFT, Cochin-682 029, India \\ ${ }^{2}$ Mumbai Research Centre of ICAR-CIFT, Vashi, Mumbai-400 703, India \\ ${ }^{3}$ Fish Processing Division, Mumbai Research Centre of ICAR-CIFT, Mumbai-400 703, India \\ ${ }^{4}$ Fish Processing Division, ICAR- CIFT, Cochin-682 029, India \\ ${ }^{5}$ EBPS, IRAD, BARC, BRIT-BARC Complex, Mumbai-400 703, India \\ ${ }^{6}$ Isotope and Radiation Applications Division, Bhabha Atomic Research Centre, Mumbai-400 085, India \\ *Corresponding Author Email : visnuvinayagam@yahoo.co.in
}

\section{Abstract}

Aim: Determination of suitable dosage for eradication of different pathogenic bacteria in water will be useful for further detailed research in this regard.

Methodology: In the current investigation, known concentration of different actively growing bacterial culture were inoculated in 96well-plate and exposed to 1, 2 and 3 kGy Electron Beam (EB) irradiation to understand the suitable destructive dosage.

Results: 1 kGy EB irradiation completely destroyed more than $2 \times$ $10^{7}$ number of $E$. coli, approximately $2 \times 10^{6}$ number of MRSA, $5 \times 10^{5}$ number of Salmonella, V. cholerae and $S$. aureus and $1 \times 10^{4}$ number of $P$. aeruginosa, respectively. Based on the study, the hierarchy of susceptible bacteria was as follows: $E$. coli $<$ MRSA $<V$. cholerae $<$ $S$. aureus < Salmonella $<P$. aeruginosa $<B$. cereus $<L$. monocytogenes.

Interpretation: The dose required for elimination of pathogens in 96 well plate was always lesser than that required for pathogens in the meat. 96-well-plate method is a simple and rapid method to assess different bacteria with different concentration in a single time and, hence, is useful and rapid technique to to determine the destructive irradiation dose for various bacteria and chemical pollutants in the substrate.

Keywords: Electron beam, Irradiation, MRSA, Pathogens, 96well-plate

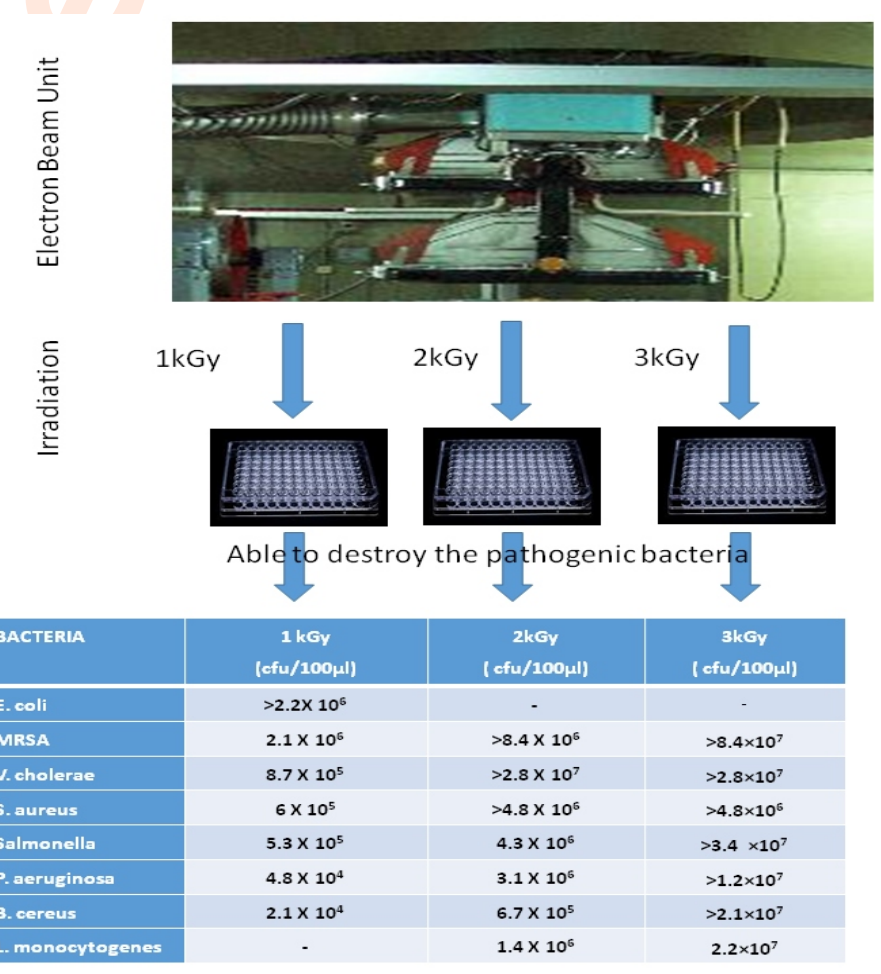

How to cite : Visnuvinayagam, S., L.N. Murthy, U. Parvathy, A. Jeyakumari, K.P. Rawat, S.A. Khadar and K.S.S. Sarma: Destructive dose determination of electron beam irradiation for pathogenic bacteria in water medium by 96 well plate assay. J. Environ. Biol., 41, 1013-1017 (2020). 


\section{Introduction}

Control of various pathogens in water is considered important to avoid the spread of water borne infection. As per World Health Organization (WHO, 2012), around 1.5 million deaths have been reported due to water borne diseases. Various processes are being followed to control pathogenic bacteria in water. Recently, Electron Beam Irradiation (EBI), a non-thermal processing technique, is gaining much attention owing to its potential antibacterial activity. Electron Beam is the flow of electrons with energy, and the energy is obtained as kinetic energy when the electron moves in a high electric field. The commercial use of EBI began in 1950s, initially applied to crosslink the polymers, i.e., polyethylene film and wire insulation. In the later decades, owing to its rapid sterilization process, it was widely practiced in most of the countries to sterilize medical devices (Waite et al., 1998). In 1980, international organizations related to food safety viz., FAO, WHO and IAEA recommended the use of irridation for food preservation with the upper limit of $10 \mathrm{kGy}$. EBI treated foods have shown dramatic reduction in food borne pathogenic bacteria, spoilage bacteria, viruses, pest and insects without any change in food quality (Jeyakumari et al., 2020).

Recently, most of the countries are interested in establishing Electron Beam Accelerator (EBA) for waste water treatment owing to its advanced oxidation processes to remove the pollutants from the waste. Wherever traditional technology is not worthy enough to remove the pollution, EBI will be a suitable alternative; hence, huge literature are available regarding degradation of pollutants from the water (Duarte et al., 2002; Nickelsen et al., 1992; Kurucz, et al., 1995). In addition, the toxic compounds present in water can also be removed using EBI (Borrely and Sampa, 2000). On account of this, EBI treated water has shown a greater improvement in its quality. Since most of the studies carried out earlier have focused on the control of chemical pollutants or dyes or other organic materials, very limited literatures are available regarding the control of pathogenic bacteria in water using EBI. Hence, the present study aimed to assess the effect of $\mathrm{EBI}$ on different bacteria in different concentrations in water by employing 96 well assay plates.

\section{Materials and Methods}

ATCC bacterial cultures: Eight types of pathogenic cultures viz., Escherichia coli, Salmonella, Vibrio cholerae, Pseudomonas aeruginosa, Bacillus cereus, Listeria monocytogenes, Staphylococcus aureus and Methicillin resistant Staphylococcus aureus were inoculated in Brain heart infusion (BHI) broth and incubated at $37^{\circ} \mathrm{C}$ till turbidity reached around $0.5 \mathrm{McF}$ Farland.

Enumeration of bacteria: Enumeration of bacterial pathogens were carried out as per Bacteriological Analytical Manual with slight modifications, i.e., one $\mathrm{ml}$ of each $0.5 \mathrm{McF}$ arland bacterial culture were transferred into $9 \mathrm{ml}$ of test tube containing PBS and
Table 1 : Comparative MBC value (cfu $100 \mu l^{-1}$ ) for different doses of electron beam irradiation

\begin{tabular}{llll}
\hline Bacteria & $1 \mathrm{kGy}$ & $\mathbf{2 k G y}$ & $3 \mathrm{kGy}$ \\
\hline E. coli & $>2.2 \times 10^{6}$ & - & - \\
MRSA & $2.1 \times 10^{6}$ & $>8.4 \times 10^{6}$ & $>8.4 \times 10^{7}$ \\
V. cholerae & $8.7 \times 10^{5}$ & $>2.8 \times 10^{7}$ & $>2.8 \times 10^{7}$ \\
S. aureus & $6 \times 10^{5}$ & $>4.8 \times 10^{6}$ & $>4.8 \times 10^{6}$ \\
Salmonella & $5.3 \times 10^{5}$ & $4.3 \times 10^{6}$ & $>3.4 \times 10^{7}$ \\
P. aeruginosa & $4.8 \times 10^{4}$ & $3.1 \times 10^{6}$ & $>1.2 \times 10^{7}$ \\
B. cereus & $2.1 \times 10^{4}$ & $6.7 \times 10^{5}$ & $>2.1 \times 10^{7}$ \\
L. monocytogenes & - & $1.4 \times 10^{6}$ & $2.2 \times 10^{7}$ \\
\hline
\end{tabular}

serially diluted (10 fold dilutions). Then, $100 \mu$ l of each dilution was taken and spread over the pre-set plate count agar (PCA) plate and incubated overnight for determining the exact number of bacteria present in $100 \mu$ l of culture.

96 well sterile cell culture plates: 96 well sterile cell culture plates were procured from Hi Media (Mumbai) and wells in all the rows were filled with $100 \mu$ l of phosphate buffer saline (PBS). A $100 \mu$ of $0.5 \mathrm{McF}$ arland known bacterial culture were inoculated in first well of first row and mixed properly and $100 \mu$ l transferred to subsequent wells in the same row to follow a two-fold dilution in subsequent wells till $12^{\text {th }}$ well. Similarly, all the pathogens were added to each first row well and 2-fold dilutions were made.

Electron beam irradiation: Electron beam accelerator (5MeV Capacity) available at Board of Radiation \& Isotope Technology (BRIT), Vashi, Navi Mumbai was utilised for the experiment. Different pathogenic bacteria were inoculated in each row with known concentration. The highest bacterial concentration in the first well and it was half quantity in subsequent well; hence, least bacterial count in the last well $\left(12^{\text {th }}\right.$ well) (highest to lowest concentration in each column) (Table 1). The plate was exposed to the 1, 2 and $3 \mathrm{kGy}$ of EBI and incubated overnight. Appearance of turbidity was considered as presence of bacteria in the wells.

\section{Results and Discussion}

In the present study, 96-well- plate was selected owing to its uniform size and thickness with universal standard; more over it is less than $2.5 \mathrm{~cm}$ and available readily with sterile condition, generally used for the assessment of virus potency (Visnuvinayagam et al., 2015a). So, other variables (errors) such as size, shape and density are kept constant; and hence the effect of $\mathrm{EBI}$ on different concentration of bacterial culture can be estimated with accuracy. The study is to determine the destructive dose for all water borne, food borne and multidrug resistant bacterial pathogens susceptible in water medium. All the referred bacterial cultures of known quantity was plated in the 96 well plates and exposed to three different doses. Based on the earlier reports, most of the bacterias are destroyed by $3 \mathrm{kGy}$ (Hossain et al., 2018). Hence, in the present study all the bacteria were 
exposed to three different dosage of EBI, i.e., 1 kGy, 2 kGy and 3 kGy.

Pathogenic bacteria viz., Salmonella, E. coli, V. cholerae food borne diseases $L$. monocytogenes, $B$. cereus, $S$. aureus (responsible for water and food borne illness) MRSA and $P$. aeruginosa (multi drug resistant) were tested to assess the resistance and susceptible nature of pathogens towards EBI.

Known concentration of each bacteria were inoculated in different wells of 96 well plate and exposed to 1,2 and $3 \mathrm{kGy}$ of $\mathrm{EBI}$ and incubated overnight. Appearance of turbidity was considered as presence of bacteria in the wells. In $1 \mathrm{kGy}$ treated plates, complete absence of turbidity was noticed on $1^{\text {st }}, 6^{\text {th }}, 5^{\text {th }}, 8^{\text {th }}$, $10^{\text {th }}, 3^{\text {rd }}$ and $2^{\text {nd }}$ well for E. coli, Salmonella, V. cholerae, $P$. aeruginosa, $B$. cereus, $S$. aureus and MRSA, respectively. In the case of $L$. monocytogenes, all the rows (even in $12^{\text {th }}$ well) exhibited turbidity. Similarly, in case of 2 kGy treated plates, absence of turbidity was observed in $1^{\text {st }}, 3^{\text {rd }}, 1^{\text {st }}, 2^{\text {nd }}, 5^{\text {th }}, 5^{\text {th }}, 1^{\text {st }}$ and $1^{\text {st }}$ wells onwards for $E$. coli, Salmonella, V. cholerae, $P$. aeruginosa, $B$. cereus, L. monocytogenes, $S$. aureus and MRSA, respectively. In $3 \mathrm{kGy}$ treated plates, all the wells were free of turbidity, except $1^{\text {st }}$ well of L. monocytogenes (Table 1).

$E$. coli is most frequently encountered pathogen in retail fish markets of India. Recent report indicated that higher levels of multi drug resistant (MDR) E. coli was observed in the fish as well as water used in the retail fish markets (Visnuvinayagam et al., 2015b; 2015c; 2016, 2018;). Extended spectrum of beta lactamase producing bacteria was also reported in the retail fish markets (Sivaraman et al., 2018). In the present study, initially the first row, first well had an $E$. coli concentration of $2.2 \times 10^{7} \mathrm{CFU}$ $100 \mathrm{\mu l}^{-1}$. However, no growth of $E$. coli was observed after subjecting it to $1 \mathrm{kGy}$ suggesting that this dose of EBI was effective in destroying all the bacteria in the first well itself.

Previous literature indicates scarce information regarding irradiation of $E$. coli in water medium. In 2013, Kundu et al. (2013) tried resistance pattern of $E$. coli by inoculating the culture in phosphate buffer saline in polypropylene tube and exposed it to $0.5-0.7 \mathrm{kGy}$ irradiation. It was found that among the 27 strains of E. coli, only 11 strains were able to resist $0.7 \mathrm{kGy}$. In the indicated study, all the cultures were prepared in pellet form and further diluted and kept in $2 \mathrm{ml}$ polypropylene vials for the experiment. However, the present study was made simple by testing in 96 well culture plates with more accurate estimation technique. Similar work done by Arthur et al. (2005) in substrate viz., beef inoculated

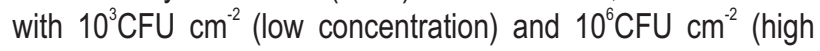
concentration) of $E$. coli and exposure to $1 \mathrm{kGy} E B I$ found complete degradation of $E$. coli for low concentration treated meat and 5.7 log reduction in high concentration treated meat.

Similar to $E$. coli, another susceptible seafood borne bacteria is Methicillin resistant Staphylococcus aureus (MRSA), an emerging multi drug resistant (MDR) pathogen. Various researches are being carried out to control the MRSA infection in human (Visnuvinayagam et al., 2019a, b). MRSA is frequently isolated from clinical samples from the hospitals and a few also reported in seafood markets of India (Murugadas et al., 2017; Sivaraman et al., 2016). But, there is no report with reference to the effect of EBI on MRSA. In the present study, 1KGy EBI was able to destroy $4.2 \times 10^{6} \mathrm{CFU} 100 \mu^{-1}$. In $2 \mathrm{kGy}$, even in the first well absence of growth was noticed indicating $2 \mathrm{kGy}$ effective in destroying even more than $8.4 \times 10^{6} \mathrm{CFU} 100 \mu \mathrm{l}^{-1}$ of MRSA. As previous data on resistance of MRSA to $E B I$ dosage is unavailable, the present work can be used as a baseline information for further research.

A dosage of $1 \mathrm{KGy}$ and $2 \mathrm{KGy}$ of EBI was able to destroy $1.75 \times 10^{6} \mathrm{CFU} 100 \mu \mathrm{l}^{-1}$ and $2.8 \times 10^{6} \mathrm{CFU} 100 \mu l^{-1}$ of $\mathrm{V}$. cholerae, respectively. Even though $V$. cholerae is well known as a water borne disease causing pathogen, there is no proper data available on its complete elimination in water, though few data are available on the effect of gamma irradiation against this pathogen. Reports indicate a $D_{10}$ value for $V$. cholerae as $1 \mathrm{kGy}$, which can effectively eliminate this pathogen from shellfish (Mallett et al., 1991).

S. aureus is the most frequently encountered pathogen in seafoods and also considered as one of the important seafood borne pathogen causing diarrhoea within short period of incubation (3 - $4 \mathrm{hrs}$ ). $S$. aureus is more susceptible to EBI next to V. cholerae. $1 \mathrm{kGy}$ and $2 \mathrm{KGy}$ of $\mathrm{EBI}$ was able to destroy $1.2 \times 10^{6}$ CFU $100 \mu l^{-1}$ and $>2.4 \times 10^{6} \mathrm{CFU} 100 \mu l^{-1}$ of $S$. aureus, respectively. No previous reports of $\mathrm{EBI}$ effect on the elimination of $S$. aureus in water medium is reported. In the present study, 1 kGy could destroy more that $1 \times 10^{6} \mathrm{~S}$. aureus cells in the water.

Among the food borne pathogens, Salmonella is one of the highly studied pathogens in meat, especially in poultry. Occurrence of Salmonella in retail market is extensively reported (Murugadas et al., 2015) and plays a major role in trade related issues due to high rejection by overseas. In the present study, 1 KGy and 2 KGy of EBI could eliminate $2.15 \times 10^{6}$ and $8.6 \times 10^{6}$ CFU $100 \mu{ }^{-1}$ of Salmonella, respectively. Complete elimination of Salmonella is influenced by various parameters leading to contradictory reports on its elimination dose. As per AbuTarboush et al. (1997), 2.5 kGy was needed for complete elimination of Salmonella, however, Lewis et al. (2002) reported that $60 \%$ of inoculated chicken breast samples were negative after $1.8 \mathrm{kGy}$ irradiation. Sarjeant et al. (2005) reported that 2.0 kGy and 3.0 kGy was able to reduce Salmonella by 3 log and 5 logs in meat. In the present study, it has been observed that $1 \mathrm{kGy}$ was sufficient to kill $10^{5}$ Salmonella present in the water.

$P$. aeruginosa is one of the multi drug resistant (MDR) bacteria causing multiple infections in human and animals. In the present study, $1 \mathrm{kGy}$ and $2 \mathrm{kGy}$ of EBI was sufficient to destroy 
$9.68 \times 10^{4}$ and $6.2 \times 10^{6} \mathrm{CFU} 100 \mu \mathrm{I}^{-1}$ of $P$. aeruginosa, respectively. Reports on the effect of EBI on $P$. aeruginosa are not available.

B. cereus is a common seafood pathogen and current study indicated that application of $1 \mathrm{kGy}$ and $2 \mathrm{kGy}$ of EBI was effective in destroying $4.21 \times 10^{4} \mathrm{CFU} 100 \mu \mathrm{I}^{-1}$ and $1.35 \times 10^{6} \mathrm{CFU}$ $100 \mu{ }^{-1}$ of this pathogen, respectively. No data is available regarding destruction of $B$. cereus in meat. However, Sarrias et al. (2003) reported a $D_{10}$ value of around $2.0-2.8 \mathrm{kGy}$ for $E B I$ with regard to $B$. cereus in rice. De Lara et al. (2002) had a comparative evaluation of $\mathrm{EBI}$ resistance of Bacillus spores and vegetative cells and reported that the vegetative form of $B$. cereus required less EBI for the elimination with a $D_{10}$ value of less than $1 \mathrm{kGy}$. However, the spore of $B$. cereus was much resistant to $E B I$ indicating even a dose of $10 \mathrm{kGy}$ to be insufficient. In the present study also, it was observed that among the tested bacteria, Listeria monocytogenes and $B$. cereus were more resistant to EBI.

L. monocytogenes is the second most studied pathogens next to Salmonella with regard to EBI application due to its high pathogenicity in both human and animals. Application of $1 \mathrm{kGy}$ $E B I$ was insufficient to destroy $2.22 \times 10^{4}$ number of $L$. monocytogenes in $100 \mu \mathrm{l}$ of broth. However, $2.85 \times 10^{6} \mathrm{CFU} 100 \mu \mathrm{l}^{-}$ ${ }^{1}$ of $L$. monocytogenes were completely destroyed by $2 \mathrm{kGy}$ EBI. 3 kGy was sufficient to destroy $2.2 \times 10^{7} \mathrm{CFU} 100 \mathrm{\mu l}^{-1}$. Zhu et al. (2009) spiked different strains of $L$. monocytogenes and irradiated with $0,1.0,1.5,2.0$, or $2.5 \mathrm{kGy}$ of $\mathrm{EBI}$ and reported $\mathrm{D}_{10}$ value ranging from 0.56 to $0.58 \mathrm{kGy}$ for $L$. monocytogenes. Similarly Su et al. (2004) observed that cold smoked salmon fish meat spiked with $10^{8} \mathrm{CFU}$ Listeria indicated $2.5 \mathrm{log}$ reduction in $1.0 \mathrm{kGy}$ treated samples and complete elimination of $L$. monocytogenes on $2.0 \mathrm{kGy}$ exposure. Rodrigo et al. (1996) reported that most of the $L$. monocytogenes were destroyed by $2.5 \mathrm{kGy}$; but, few of the strains of $L$. monocytogenes were stable to $\mathrm{EBI}$ at lower dose. They recommended $4.5 \mathrm{kGy}$ to be effective in completely eliminating $L$. monocytogenes. Based on the previous reports, it was observed that most of the $L$. monocytogenes strains were destroyed in meat after exposure to 2 - $2.5 \mathrm{kGy}$, however few strains required around $4.5 \mathrm{kGy}$ for complete elimination from the meat.

Various researches conducted on the effect of irradiation on waste water treatment improved the water quality occurred on treatment with 40 to $120 \mathrm{kGy}$ irradiation (Gu et al., 2017). Based on the previous work, it has been observed that, high doses of EBI are needed to degrade chemical or organic pollutants from the waste. However, to destroy pathogenic bacteria comparatively very low doses are sufficient. Production of three types of transient species is the cause for the antimicrobial property of $\mathrm{EBI}$. These transient species are formed in water while hitting water with high energy electron beam, viz. aqueous electron (eaq), hydrogen radical (H.) and hydroxyl radical (.OH) (Waite et al., 1998).
Monk et al. (1995) clearly described that the death of bacteria by irradiation is influenced by many external factors such as $\mathrm{pH}$, temperature, chemical composition of food in which the bacterial cells are suspended. In addition, the concentration of bacteria and surface distribution of meat also plays a significant role. Since, damage to bacterial DNA is the main factor for destruction; bacteria with poor DNA repair mechanism are highly sensitive to irradiation (Monk et al., 1995). In Gamma Irradiation (GI) even the lower doses can cause adverse effects in the sensory characteristics of meat substrate, while it is negligible as far as EBI is concerned. The present study indicated the hierarchy of susceptibility of different bacteria to $E B I$ is the following order: E. coli $<$ MRSA $<$ V. cholerae $<S$. aureus $<$ Salmonella $<P$. aeruginosa $<B$. cereus $<L$. monocytogenes.

The current investigation concludes that 96 well plate study was proved to be an effective, simple and rapid technique to determine the destructive dose of EBI on different bacteria.

\section{Acknowledgments}

Authors thankfully acknowledge the Director, ICARCIFT, Cochin, Kerala for providing necessary facilities to carry out the research work. We duly acknowledge Mrs. Thriveni Adiga, Chief Technical Officer and Mr. Tulshiram A. Waghmare, Senior Technician, ICAR- Mumbai Research Centre of CIFT, Navi Mumbai, Maharashtra for the support in microbiological analyses.

\section{References}

Abu-Tarboush, H.M., H.A. Al-Kahtani, M. Atia, A.A. Abou-Arab, A.S. Bajaber and M.A. EL-Mojaddid: Sensory and microbial quality of chicken as affected by irradiation and post-irradiation storage at $4.0^{\circ}$ C. J. Food Prot., 60, 761-770 (1997).

Arthur, T.M., T.L. Wheeler, S.D. Shackelford, J.M. Bosilevac, X. Nou and M. Koohmaraie: Effects of low-dose, low-penetration electron beam irradiation of chilled beef carcass surface cuts on Escherichia coli 0157: H7 and meat quality. J. Food Prot., 68, 666672 (2005).

De Lara, J., P.S. Fernández, P.M. Periago and A. Palop: Irradiation of spores of Bacillus cereus and Bacillus subtilis with electron beams. Inn. Food Sci. Emer. Technol., 3, 379-384 (2002).

Duarte, C.L., M.H.O. Sampa, P.R. Rela, H. Oikawa, C.G. Silveira and A. L. Azevedo: Advanced oxidation process by electron-beamirradiation-induced decomposition of pollutants in industrial effluents. Rad. Phy. Chem., 63, 647-651 (2002).

Gu, J.E., G. Son, H. Lee, J. Park, Y.N. Kwon and S. Lee: Improved water quality and phenol degradation via a combination of electronbeam irradiation (EBI) and activated carbon fiber (ACF). Desalin. Water Treat., 64, 118-126 (2017).

Hossain, K., Y.A. Maruthi, N.L. Das, K.P. Rawat and K.S.S. Sarma: Irradiation of wastewater with electron beam is a key to sustainable smart/green cities: Areview. App. Water Sci, 8, p. 6 (2018).

Jeyakumari A. ,S. Visnuvinayagam, U. Parvathy K.S.S. Sarma, K.S. Rawat, S. A. Khadar, L.N. Murthy and C.N. Ravishankar: Effect of electron beam irradiation on the biochemical, microbiological and sensory quality of Litopenaeus vannamei during chilled storage. J. 
Food Sci. Technol., 57, 2150-2158 (2020).

Kundu, D., A. Gill and R. Holley: Use of low-dose irradiation to evaluate the radiation sensitivity of Escherichia coli 0157: H7, non-0157 verotoxigenic Escherichia coli, and Salmonella in phosphatebuffered saline. J. Food Prot., 76, 1438-1442 (2013).

Kurucz, C.N., T.D. Waite, W.J. Cooper and M.G. Nickelsen: Empirical models for estimating the destruction of toxic organic compounds utilizing electron beam irradiation at full scale. Rad. Phys. Chem., 45, 805-816 (1995).

Lewis, S.J., A. Velasquez and S.L. Cuppett: Effect of electron beam irradiation on poultry meat safety and quality: Poul. Sci., 81, 896$903(2002)$.

Mallett, J.C., L.E. Beghian, T.G. Metcalf and J.D. Kaylor. Potential of irradiation technology for improved shellfish sanitation. J. Food Safety, 11, 231-245(1991).

Monk, J.D., L.R. Beuchat and M.P. Doyle: Irradiation inactivation of foodborne microorganisms. J. Food Protect., 58, 197-208 (1995).

Murugadas, V., S. Visnuvinayagam, V. Purushothaman, T.G. Prabhakar, P. Prabhahar and K. Ventakaraman: Prevalence of chicken host and non-host adapted Salmonella in retail outlet of Chennai, India. Asi. J. Ani. Veter. Advan., 10, 885-893 (2015).

Murugadas, V., T.C. Joseph and K.V. Lalitha: Tracing contamination of Methicillin-resistant Staphylococcus aureus (MRSA) into seafood marketing chain by staphylococcal protein A typing. Food Control, 78, 43-47 (2017).

Nickelsen, M.G., W.J. Cooper, C.N. Kurucz and T.D. Waite: Removal of benzene and selected alkyl-substituted benzenes from aqueous solution utilizing continuous high-energy electron irradiation. Environ. Sci. Technol., 26, 144-152(1992).

Rodrigo, T.R., E.A. Murano and D.G. Olson: Survival and injury of Listeria monocytogenes, Listeria innocua and Listeria ivanovii in ground pork following electron beam irradiation. J. Food Protec., 59, 596600 (1996)

Sarjeant, K.C., S.K. Williams and A.H. Jr: The effect of electron beam irradiation on the survival of Salmonella enterica's typhimurium and psychrotrophic bacteria on raw chicken breasts stored at four degrees celsius for fourteen days. Poultry Sci., 84, 955-958 (2005).

Sarrias, J.A., M. Valero and M.C. Salmeron: Elimination of Bacillus cereus contamination in raw rice by electron beam irradiation. Food Microbiol., 20, 327-332 (2003).

Sivaraman, G.K., S. Visnuvinayagam, A.K. Jha, V. Renuka, S. Remya and $V$. Deesha: Assessment of microbial quality of fish processing industrial effluent in bar-mouth at Bhidia landing site, Veraval, Gujarat, India. J. Environ. Biol., 37, 537-541 (2016).

Sivaraman, G.K., D. Vanik, M.M. Prasad, S. Visnuvinayagam, K.A. Basha, R.K. Nadella, A.K. Jha and C. Vaja: Detection of chromosomal AmpC, bla CTX-M in extended spectrum beta lactamase producing Escherichia coli in seafood processing effluent. Proceedings of the National Academy of Sciences, India Section B: Biological Sciences, 88, 1265-1273 (2018).

$\mathrm{Su}$, Y.C., J. Duan and M.T. Morrissey: Electron beam irradiation for reducing Listeria monocytogenes contamination on cold-smoked salmon. J. Aqu. Food Prod. Technol., 13, 3-11(2004).

Visnuvinayagam, S., K. Thangavel, N. Lalitha, S. Malmarugan and K. Sukumar: Assessment of the pathogenicity of cell-culture-adapted Newcastle disease virus strain Komarov. Braz. J. Microbiol., 46, 861-865 (2015a).

Visnuvinayagam, S., T.C. Joseph, V. Murugadas, R. Chakrabarti and K.V. Lalitha: Status on methicillin resistant and multiple drug resistant Staphylococcus aureus in fishes of Cochin and Mumbai coast, India. J. Environ. Biol., 36, 571-575 (2015b).

Visnuvinayagam, S., P. Viji, P.K. Binsi, R. Chakrabarti, A. Triveni, C.G. Joshy and K.V. Lalitha: Effect of monsoon on sulphite reducing clostridia level in fish from retail outlets in Maharashtra. Fish. Technol., 52, 198-201 (2015c).

Visnuvinayagam, P., P. Viji, L.N. Murthy, A. Jeyakumari and G.K. Sivaraman: Occurrence of faecal indicators in freshwater fishes of Navi Mumbai in retail outlets. Fish. Technol., 53, 334- 338 (2016).

Visnuvinayagam, S., L.N. Murthy, P. Viji and G.K. Sivaraman: Study on retail fish markets: Possible occurrence and transmission of emerging pathogen from faecal indicators. J. Environ. Biol., 38, 465- 470 (2017).

Visnuvinayagam, S., L.N. Murthy, U. Parvathy, A. Jeyakumari, T.G. Adiga and G.K. Sivaraman: Detection of multi drug resistant bacteria in retail fish market water samples of Vashi, Navi Mumbai. Proceedings of the National Academy of Sciences, India Section B: Biological Sciences, 89, 59-564 (2019a).

Visnuvinayagam, S., L.N. Murthy, A. Jeyakumari, U. Parvathy, R. Anandan, G.K. Sivaraman and C.N. Ravishankar: Combined effect of zinc oxide nano particle incorporated chitosan for better antimicrobial activity towards wound healing. J. Environ. Biol., 40, 691-697 (2019b).

Waite, T.D., C.N. Kurucz, W.J. Cooper and D. Brown: Full scale electron beam systems for treatment of water, wastewater and medical waste (No. IAEA-TECDOC--1023) (1998).

WHO, 2012. Water sanitation, Word Health Organization, hygiene, Geneva, Switzerland,https://www.who.int /water_sanitation_ health/diseases-risks/en/

Zhu, M.J., A. Mendonca, H.A. Ismail and D.U. Ahn: Fate of Listeria monocytogenes in ready-to-eat turkey breast rolls formulated with antimicrobials following electron-beam irradiation. Poultry Sci., 88, 205-213 (2009). 